\title{
Genetic resistance of eight native Egyptian chicken breeds having chicken B-cell marker 6 gene post-challenge with field strain of Marek's disease-induced tumor virus
}

\author{
Hala A. Shaheen ${ }^{1}$, H. A. Hussein ${ }^{2}$, M. M. Elsafty ${ }^{1}$ and M. A. Shalaby ${ }^{2}$ \\ 1. Central Laboratory for Evaluation of Veterinary Biologics, Cairo, Egypt; 2. Department of Virology, Faculty of Veterinary \\ Medicine, Cairo University, Giza, Egypt. \\ Corresponding author: Hala A. Shaheen, e-mail: ahmadhala62@yahoo.com \\ Co-authors: HAH: husvirol@cu.edu.eg, MME: melsafty_hobs@yahoo.com, MAS: mshalaby43@gmail.com \\ Received: 08-07-2018, Accepted: 24-09-2018, Published online: 29-10-2018
}

doi: 10.14202/vetworld.2018.1510-1515 How to cite this article: Shaheen HA, Hussein HA, Elsafty MM, Shalaby MA (2018) Genetic resistance of eight native Egyptian chicken breeds having chicken B-cell marker 6 gene post-challenge with field strain of Marek's disease-induced tumor virus, Veterinary World, 11(10): 1510-1515.

\begin{abstract}
Aim: The aim of this work was to detect chicken B-cell marker 6 (ChB6) gene in some native breeds in Egypt and find the relationship between founded genes in these different breeds to determine the resistance of native Egyptian breeds of chicken to Marek's disease (MD).

Materials and Methods: A total of 14 different chicken breeds (30 each) including ten native breeds in addition to SPF Lohmann, High Line, Bovans, and Roodiland were used. Blood samples were collected for the detection of (ChB6) by polymerase chain reaction (PCR) assay and sequenced to determine the presence or absence of ChB6 gene. Experimental infection was done using local field isolated MD virus (MDV) of 11 (1 day old) unvaccinated chick breeds having no maternal antibodies against MDV. Ten breeds of them carry ChB6 gene, eight breeds were native, and the rest two breeds were SPF Lohmann and High Line in addition to a group of ChB6 gene-lacking breed (Bovans) were infected. Spleen samples were collected from all infected breeds at $20^{\text {th }}, 25^{\text {th }}, 30^{\text {th }}, 35^{\text {th }}$, and $40^{\text {th }}$ weeks post-infection and tested by PCR assay for the detection of MDV. Furthermore, at $40^{\text {th }}$ week post-infection, tumorized spleen sample of Bovans breed was collected and prepared for examination by transmission electron microscope (TEM) to confirm the presence of MDV.

Results: Our results revealed the positivity of 10 out of 14 breeds (Gimmizah, Sinai, Dandarawi, Fayoumi, Golden Montazah, Matrouh, Beheri, Dokki, SPF Lohmann, and High Line) to the presence of ChB6 gene and resistance to MDV infection, while the Bovans, Mandarah, Inshas and Roodiland breeds lack the $C h B 6$ gene and are susceptible to MDV infection. The collected spleen samples revealed negative for the presence of challenged MDV by PCR in 10 breeds (Gimmizah, Sinai, Dandarawi, Fayoumi, Golden Montazah, Matrouh, Beheri, Dokki, SPF Lohmann, and High Line) and positive for Bovans breed. TEM is used to confirm MDV infection in Bovans group which demonstrated tumors.
\end{abstract}

Conclusion: The study confirms the relationship between the presence of ChB6 gene in our native breeds and the absence of tumors.

Keywords: ChB6 gene, Egyptian chicken breeds, Marek's disease, polymerase chain reaction, transmission electron microscope.

\section{Introduction}

Marek's disease (MD) is a complex, immunosuppressive lymphomatous which induces T-lymphoma and neuropathic disease of domestic fowl caused by an alphaherpesvirus characterized by paralysis, chronic wasting, lymphoma development in the viscera and musculature, and blindness in chickens. MD symptoms vary in severity based on virus strain as well as bird genotype and vaccination status with death occurring in susceptible, non-immunized chickens. MD occurs at 3-4 weeks of age or older and is the most

Copyright: Shaheen, et al. Open Access. This article is distributed under the terms of the Creative Commons Attribution 4.0 International License (http://creativecommons.org/licenses/ by/4.0/), which permits unrestricted use, distribution, and reproduction in any medium, provided you give appropriate credit to the original author(s) and the source, provide a link to the Creative Commons license, and indicate if changes were made. The Creative Commons Public Domain Dedication waiver (http:// creativecommons.org/publicdomain/zero/1.0/) applies to the data made available in this article, unless otherwise stated. common between 12 and 30 weeks of age. Chickens may persistently infect with MD virus (MDV) without developing clinical disease. Diagnosis is made on clinical signs and gross/microscopic lesions.

Infection by MDV can be detected by virus isolation and the detection of viral antigen or antibodies. In chickens, tumors that resemble those produced by MDV have to be differentiated from avian retroviruses such as avian leukosis virus and reticuloendotheliosis virus [1-3]. However, successful vaccination control these diseases but losses still occur [4].

There are three lymphocyte surface antigens (Bu-1, Thy-1, and Ly-4) associated with the resistance against MDV [5]. The gene coding for $\mathrm{Bu}-1$ has been isolated [6] and designated as chicken B-cell marker 6 (ChBO) which is highly glycosylated membrane protein expressed on chicken B lymphocytes through most of their development and shows a significant association with resistance. The mechanism of resistance was unknown in 1990, later on, they found that 
the $C h B 6$ as a $\mathrm{B}$ cell surface antigen induces a physiological signal for apoptosis in self-reactive lymphocytes, thus preventing autoimmune diseases in birds $[7,8]$.

This study can enhance the breeding program of these breeds in Egypt. The present study was designated to investigate the ChB6 gene presence and find the relationship between them in some different poultry breeds in Egypt through phylogram.

\section{Materials and Methods \\ Ethical approval}

Adequate measures were taken to minimize pain and animal discomfort. Experiments were carried out in accordance with the guidelines laid down by the International Animal Ethics Committee and in accordance with local laws and regulations.

\section{Chicken breeds}

Fourteen different chicken breeds (30 each) including native breeds, namely Mandarah, Gimmizah, Sinai, Dandarawi, Inshas, Fayoumi, Golden Montazah, Matrouh, Beheri, and Dokki, SPF Lohmann, High Line, Bovans, and Roodiland. All groups were reared in separated isolators.

\section{Polymerase chain reaction (PCR) assay for detect- ing the presence of $\mathrm{ChB} 6$ gene in these 14 chicken breeds}

Blood samples were collected in K EDTA tube vacutainer (VOMA MED ${ }^{\circledR}$ lot No.150302) and then transported in ice-box to the laboratory, and the DNA extraction step was done for the detection of the resistant gene to MD ( $C h B \sigma)$ by PCR assay.

Primers amplified a 215-bp fragment (BIOFLUX kit, cat No. BSC06S1.) covering exon 3 from genomic DNA. The PCR was performed in a total volume of $25 \mu \mathrm{L}$, containing $25 \mathrm{ng}$ of genomic DNA, $0.8 \mu \mathrm{L}$ of each oligonucleotide (nt) primer (F: 5'-GCTTCCCCAATGGAACTG-3' and R: 5' GAGCACAATGGGCCTAGTC-3' and master mix kit MY Taq ${ }^{\mathrm{TM}}$ Red mix), $2.5 \mu \mathrm{L}$ of $10 \times \mathrm{PCR}$ reaction buffer, $1.5 \mathrm{mM} \mathrm{MgCl} 2,200 \mu \mathrm{L}$ of each deoxynucleotide (dNTP), and $1 \mathrm{U}$ of Taq DNA polymerase. Cycling parameters included initial cycle of $94^{\circ} \mathrm{C}$ for $5 \mathrm{~min}$, then 35 cycles of $94^{\circ} \mathrm{C}$ for $1 \mathrm{~min}, 55^{\circ} \mathrm{C}$ for $1 \mathrm{~min}$, and $72^{\circ} \mathrm{C}$ for $1 \mathrm{~min}$, with a final extension step of $15 \mathrm{~min}$ at $72^{\circ} \mathrm{C}[9,10]$.

The electrophoreses of the PCR product were carried out using agarose (1\%) of molecular biology grade containing ethidium bromide with a final concentration of $0.5 \mu \mathrm{g} / \mathrm{ml}$ at $75 \mathrm{~V}$ for $15 \mathrm{~min}$ in $1 \times \mathrm{TBE}$ buffer, against GeneRulerTM100 bp Plus DNA Ladder (ferments). The expected product of corrected size (215 bp) was visualized and photographed using UV Transilluminator BioDoc Analyze Digital Systems (Biometra, Germany) and Polaroid films [9].

\section{Nt sequence of $P C R$ products}

The PCR products were subjected to sequencing. Amplified DNA band of the PCR product was excised and purified from the gel using QIAquick PCR
Product Extraction Kit (Qiagen Inc., Valencia, CA) according to the manufacturer instruction. The purified PCR products were sequenced by Biosystems 3130 automated DNA sequencer (ABI, 3130, USA), and the data were analyzed by BioEdit software with similar sequence from GenBank National Center for Biotechnology Information (NCBI) [6,11]. Nt sequences of $C h B 6$ (accession number X92865) were used to search in the GenBank (NCBI) for nt and amino acid analysis [11].

Assembly of the consensus sequences and alignment trimming was performed with the laser gene DNASTAR group of programs (DNASTAR Inc., Madison, WI), using Clustal W method [11,12]. The gene alignment identity, divergence percentage, and phylogram were carried out and drawn using DNA star - MegAlign software [11-12-13].

A phylogenetic tree is comparing the relatedness of the sequence of the $C h B 6$ gene in different positive chicken breeds with other similar ChB6 genes sequence from GenBank of the world using MEGA6 software [11,13].

\section{Experimental design}

MDV local field isolate was isolated and characterized in 2015 from tumor samples of MD-infected flock. The virus was detected by PCR assay using a set of primers FP: GGATCG CCC AC CACG ATTAC TACC and RP: ACTG CCT CACACAACC TCATC TCC [14]. The utilized isolated MDV was titrated in duck embryo fibroblast (DEF) according to Thornton [15], and used for the experimental infection of chicks of different breeds. Eight different native breeds namely (Gimmizah, Sinai, Dandarawi, Fayoumi, Golden Montazah, Matrouh, Beheri, Dokki) in addition to SPF Lohmann, and High Line of 1 day old which carry $C h B 6$ gene and group of chicken (Bovans) which lacks $C h B 6$ gene of 1 day old and all have no maternal antibodies against MDV [16] were used for the experiment.

Eight hundred and twenty-five of 1-day-old chicks were divided into 11 different groups each group of 75 chicks, and all groups were experimentally infected subcutaneously with $0.5 \mathrm{~mL}$ MDV separately $1 \times 10^{3} \mathrm{PFU}$ [17]. Spleen samples were collected from all infected groups at $20^{\text {th }}, 25^{\text {th }}, 30^{\text {th }}, 35^{\text {th }}$, and $40^{\text {th }}$ weeks post-infection from different groups and tested by PCR assay for the detection of MDV [18]. Furthermore, at $40^{\text {th }}$ week post-infection, tumorized spleen sample of Bovans breed was collected and prepared for examination by transmission electron microscope (TEM) to confirm the presence of MDV [19].

\section{Results}

The PCR amplification for the detection of ChB6 gene in these 14 chicken breeds concluded that the ChB6 gene was found in 10 breeds (A-J) as they showed positive amplification for $C h B 6$ gene at $215 \mathrm{bp}$, while the rest four breeds (K-N) were negative to the $C h B 6$ gene (Table-1 and Figure-1). 
Table-1: The detection of ChB6 gene in different 14 chicken breeds.

\begin{tabular}{|c|c|c|c|c|c|}
\hline Group No & $\begin{array}{l}\text { Code number } \\
\text { of breeds }\end{array}$ & Name of the breeds & Source of the breeds & $\begin{array}{l}\text { Number of the } \\
\text { chicken in each breed }\end{array}$ & $\begin{array}{l}\text { Detection of } \\
\text { ChB6 gene }\end{array}$ \\
\hline 1 & $A$ & Dokki & Elazzab project in fayoum & 30 & Positive \\
\hline 2 & B & Gimmizah & Elazzab project in fayoum & 30 & Positive \\
\hline 3 & $\mathrm{C}$ & Sinai & Elazzab project in fayoum & 30 & Positive \\
\hline 4 & D & Dandarawi & Elazzab project in fayoum & 30 & Positive \\
\hline 5 & $\mathrm{E}$ & Fayoumi & Elazzab project in fayoum & 30 & Positive \\
\hline 6 & $\mathrm{~F}$ & Golden Montazah & Elazzab project in fayoum & 30 & Positive \\
\hline 7 & G & Matrouh & Elazzab project in fayoum & 30 & Positive \\
\hline 8 & $\mathrm{H}$ & SPF Lohmman & Koom osheem in Fayoum & 30 & Positive \\
\hline 9 & I & Beheri & Elazzab project in fayoum & 30 & Positive \\
\hline 10 & j & Layer breed High Line & & 30 & Positive \\
\hline 11 & $\mathrm{~K}$ & Layer breed bovans & & 30 & Negative \\
\hline 12 & $\mathrm{~L}$ & Mandarah & Elazzab project in Fayoum & 30 & Negative \\
\hline 13 & M & Inshas & Elazzab project in fayoum & 30 & Negative \\
\hline 14 & $\mathrm{~N}$ & Roodiland & Elazzab project in fayoum & 30 & Negative \\
\hline
\end{tabular}

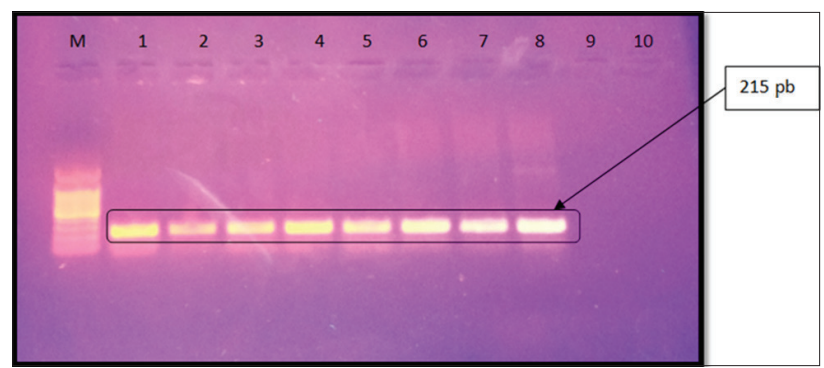

Figure-1: Demonstrate electrophoresis of the amplified products for detection of the ChB6 gene. M represents the 100 bp molecule PCR marker. Lanes 1-8 represent the specific PCR product of positive breeds at the correct expected size for ChB6 (215 bp). Lanes 9 and 10 were negative.

The genomic sequencing (nt and amino acid analysis) of chicken ChB6 detected the presence of $C h B 6$ gene in the 10 positive chicken breeds and other similar gene sequences from GenBank. Each set row is a total of $150 \mathrm{nt}$. Dots indicate the position where the sequence is identical to the consensus (Figures-2-4 and Table-2).

The nt sequence showed identity range from $98 \%$ to $100 \%$ to the ChB6 gene in 10 different positive breeds and other similar sequences from GenBank. Each set row is a total of 50 amino acids. Dots indicate the position where the sequence is identical to the consensus.

\section{Experimental infection trial}

The isolated virus was obtained from liver and spleen samples of some Kaloubia layer farms which revealed positive amplification of MDV by PCR assay to be ready for experimental infection (Figure-5).

After infection of DEF by different dilutions of the isolated virus, the titer was $10^{4} \mathrm{PFU} / 0.5 \mathrm{ml}$. The collected spleen samples at $25,30,35$, and 40 weeks post-infection were detected by PCR assay, the groups (A-J) revealed negative amplification of $247 \mathrm{bp}$ of MDV gene, whereas spleen samples collected from groups $(\mathrm{K})$ revealed positive amplification at $247 \mathrm{bp}$ of MDV gene (Figure-6).

\section{Electron microscope characterization of reisolated MDV}

The result of TEM indicated the presence of MDV viral particles in the cytoplasm of lymphocytes and macrophages in spleen sample of 40 weeks post-infection in susceptible breed having no ChB6 gene (Bovans) (Figure-7).

\section{Discussion}

The major goal in the current animal breeding industry is to improve animal health [20]. By genetic control of resistance to pathogens, we can reduce the disease-related costs and losses in addition to improvement of the immune capacity of animals. The complex immune system of poultry provides an opportunity for investigating polygenic regulation of immune response in chickens [21].

The ChB6 gene has been proposed as a candidate gene in regulating the development of B-cell [5]. The ChB6 gene is expressed on the B-cell precursor in the chicken embryo and some macrophages [22,23]. It was previously reported that $C h B 6$ is associated with the expression level of major histocompatibility complex (MHC) Class II, regression of Rous sarcoma, and resistant to $\mathrm{MD}[6,24,25]$. Morever, also, ChB6 is mapped on chromosome [26].

The chicken B-cell marker ( $C h B$ 6) gene is considered as a candidate gene in the regulation of B-cell development [6]. ChB6 was associated with the resistance to $\mathrm{MD}$, regression of $R$. sarcoma, and expression level of MHC Class II [6,24]. In the present study, we tested 14 breeds for the presence of ChB6 gene to investigate the resistance of such breeds to MDV-induced tumors. No reports have been published to document the resistance of these breeds to MDV.Results have shown that ChB6 gene was detected in 10 native breeds (Gimmizah, Sinai, DandarawiFayoumi, Golden Montazah Matrouh Beheri Dokki), also in SPF Lohmann, and High Line breeds; no reports have been published the occurrence of tumor in such breed, while the other four tested breeds (Bovans, Elmandra, Anshase, and Roodiland) were negative to the $C h B 6$ gene. 
Available at www.veterinaryworld.org/Vol.11/October-2018/24.pdf

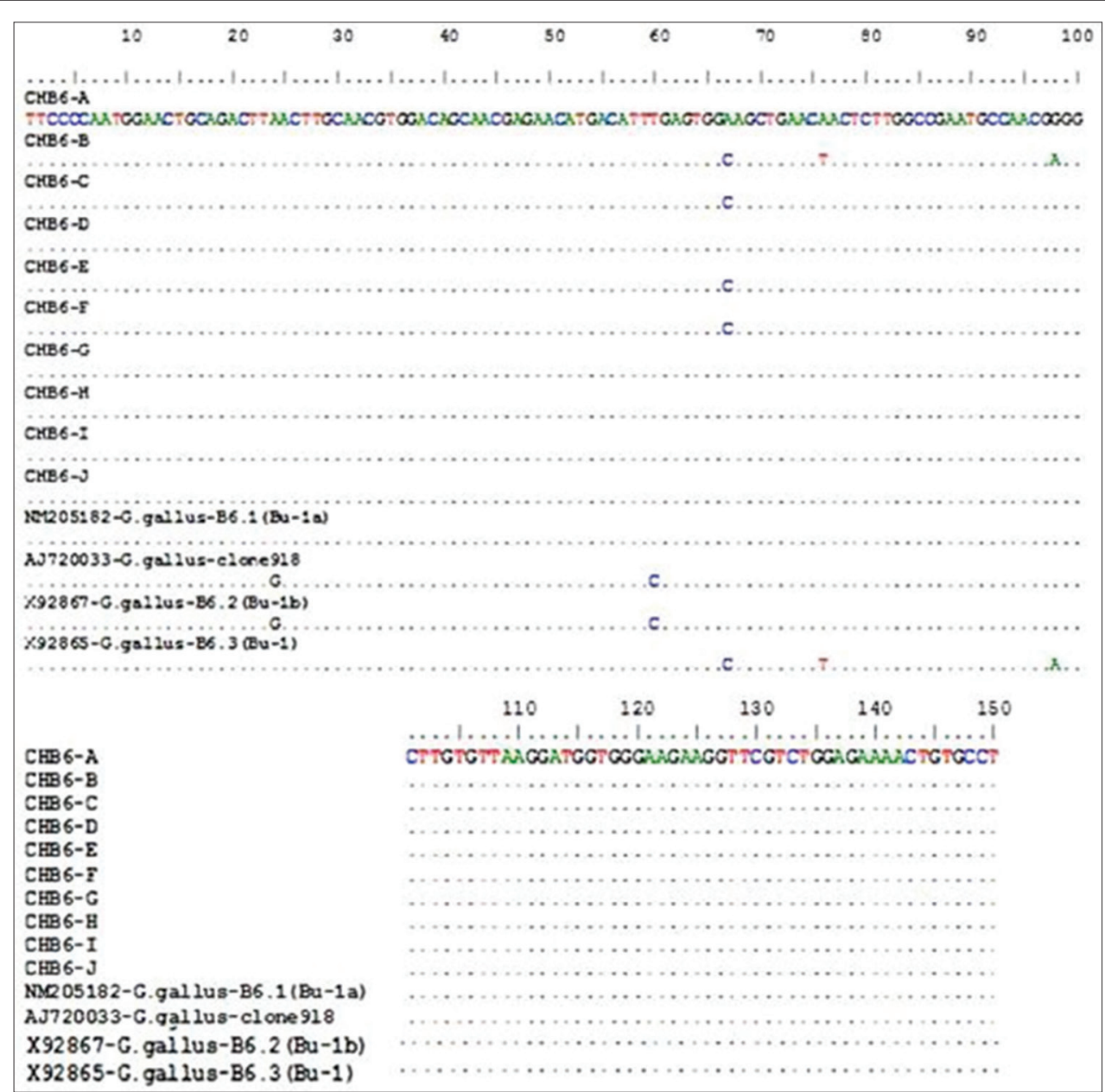

Figure-2: Nucleotide (nt) alignment of ChB6 gene using Clustal format alignment by BioEdit (V6.5), ChB6 gene sequence for the alignment of $\mathrm{nt}$.

Table-2: Identity and diversity percentage of the ChB6 gene compared to some reference genes.

\begin{tabular}{|c|c|c|c|c|c|c|c|c|c|c|c|c|c|c|c|}
\hline & Seq ID & 1 & 2 & 3 & 4 & 5 & 6 & 7 & 8 & 9 & 10 & 11 & 12 & 13 & 14 \\
\hline 1 & ChB6-A & & 98 & 99 & 100 & 99 & 99 & 100 & 100 & 100 & 100 & 100 & 99 & 99 & 98 \\
\hline 2 & ChB6-B & 98 & & 99 & 98 & 99 & 99 & 98 & 98 & 98 & 98 & 98 & 97 & 97 & 100 \\
\hline 3 & ChB6-C & 99 & 99 & & 99 & 100 & 100 & 99 & 99 & 99 & 99 & 99 & 98 & 98 & 99 \\
\hline 4 & ChB6-D & 100 & 98 & 99 & & 99 & 99 & 100 & 100 & 100 & 100 & 100 & 99 & 99 & 98 \\
\hline 5 & ChB6-E & 99 & 99 & 100 & 99 & & 100 & 99 & 99 & 99 & 99 & 99 & 98 & 98 & 99 \\
\hline 6 & ChB6-F & 99 & 99 & 100 & 99 & 100 & & 99 & 99 & 99 & 99 & 99 & 98 & 98 & 99 \\
\hline 7 & ChB6-G & 100 & 98 & 99 & 100 & 99 & 99 & & 100 & 100 & 100 & 100 & 99 & 99 & 98 \\
\hline 8 & ChB6-H & 100 & 98 & 99 & 100 & 99 & 99 & 100 & & 100 & 100 & 100 & 99 & 99 & 98 \\
\hline 9 & ChB6-I & 100 & 98 & 99 & 100 & 99 & 99 & 100 & 100 & & 100 & 100 & 99 & 99 & 98 \\
\hline 10 & ChB6-J & 100 & 98 & 99 & 100 & 99 & 99 & 100 & 100 & 100 & & 100 & 99 & 99 & 98 \\
\hline 11 & NM205182-G. gallus-B6.1 (Bu-1a) & 100 & 98 & 99 & 100 & 99 & 99 & 100 & 100 & 100 & 100 & & 99 & 99 & 98 \\
\hline 12 & AJ720033-G. gallus-clone918 & 99 & 97 & 98 & 99 & 98 & 98 & 99 & 99 & 99 & 99 & 99 & & 100 & 97 \\
\hline 13 & X92867-G. gallus-B6.2 (Bu-1b) & 99 & 97 & 98 & 99 & 98 & 98 & 99 & 99 & 99 & 99 & 99 & 100 & & 97 \\
\hline 14 & X92865-G. gallus-B6.3 (Bu-1) & 98 & 100 & 99 & 98 & 99 & 99 & 98 & 98 & 98 & 98 & 98 & 97 & & \\
\hline
\end{tabular}

Gallus gallus $=$ G. gallus

Amplification of $215 \mathrm{bp}$ fragment in PCR reaction confirms the correct expected size of the ChB6 gene [9]. Such PCR assay was previously reported by Tregaskes et al. [6] and O'Laughlin [27], and the results of the present study confirm the specificity of utilized primers in the PCR reaction. Sequencing of the amplified product of ChB6 gene revealed that there is a high similarity between the 10 positive chicken breeds (Gimmizah, Sinai, Dandarawi,
Fayoumi, Golden Montazah, Matrouh, Beheri Dokki, SPF Lohmann, and High Line).

As previously reported, the similarity in the ChB6 in different breeds was high [6,10]. Such similarity was also reported when we search on the reported sequences in GenBank [9,27]. The homology percentage ranged between $98 \%$ and $100 \%$ in the 10 positive breeds confirms the conservation of ChB6 gene. Greatest identity in the hypervariable 


\begin{tabular}{|c|c|}
\hline & 10 \\
\hline & $\ldots \ldots|\ldots| \ldots|\ldots| \ldots|\ldots \ldots| \ldots|\ldots \ldots| \ldots \ldots|\ldots \ldots| \ldots \mid$ \\
\hline CHB 6-A & EPNGTADLTCINDSNENMTEVWLLNSSWPNANGACVKDGCKKVRLEKTVP \\
\hline CHB 6-B & \\
\hline CEB 6-C & \\
\hline CHB6-D & \\
\hline CHB 6-E & …................. 0. \\
\hline CHB6- $\mathbf{I}$ & ....... 0. \\
\hline CHB 6-G & …...................................... \\
\hline CHB6-H & ㅅ․ \\
\hline CHB6-I & 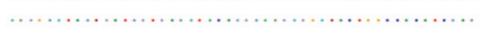 \\
\hline CHB6-J & n............... \\
\hline NM205182-G.gallus-B6.1(Bu-1a) & (n............... \\
\hline AJ720033-G.gallus-clone 918 & ........ \\
\hline X92867-G. gallus-B6.2(Bu-1b) & ...... \\
\hline X92865-G. gallus-B6.3 (Bu-1) & … \\
\hline
\end{tabular}

Figure-3: Alignment of ChB6 gene using Clustal format alignment by BioEdit (V6.5), ChB6 gene sequence for the alignment of amino acid in the 10 positive groups and other similar sequences from GenBank.

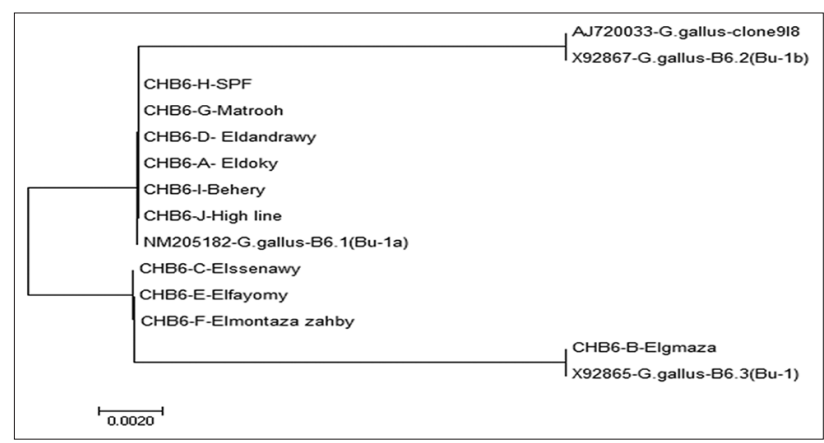

Figure-4: Phylogenetic tree of nucleotide sequences of ChB6 gene in 10 different positive breeds and other related breeds from GenBank.

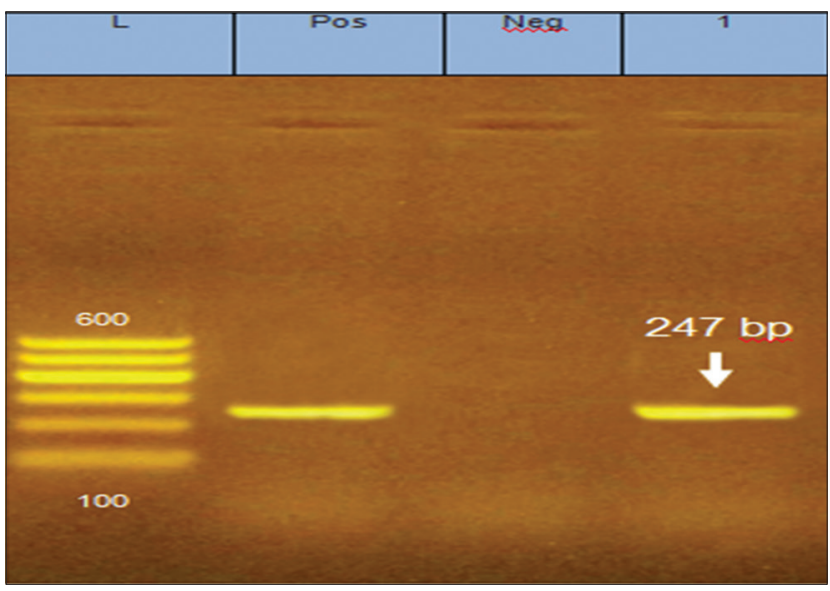

Figure-5: Polymerase chain reaction for the tissue samples (liver and spleen) infected by Marek's disease virus. $L$ for 100 bp ladder. Pos - Positive control. Neg - negative control. 1 sample.

region analyzed in the obtained sequences has been noticed. Such identity was reported in all 10 positive breeds and also in other sequences found in GenBank. Sequence analysis of the $150 \mathrm{nt}$ fragments of the amplified ChB6 gene was obtained and was submitted to NCBI GenBank under Accession Number AJ720033-Gallus gallus-clone918, X92867-G. gallus-B6.2 (Bu-1b), X92865-G. gallus-B6.3 (Bu-1), and NM205182-G. gallus-B6.1 (Bu-1a). The sequence of ChB6 gene from the 10 positive breeds was aligned. $\mathrm{Nt}$ sequence analysis revealed the grate identity between Matrouh, Beheri, Dokki, SPF Lohmann,

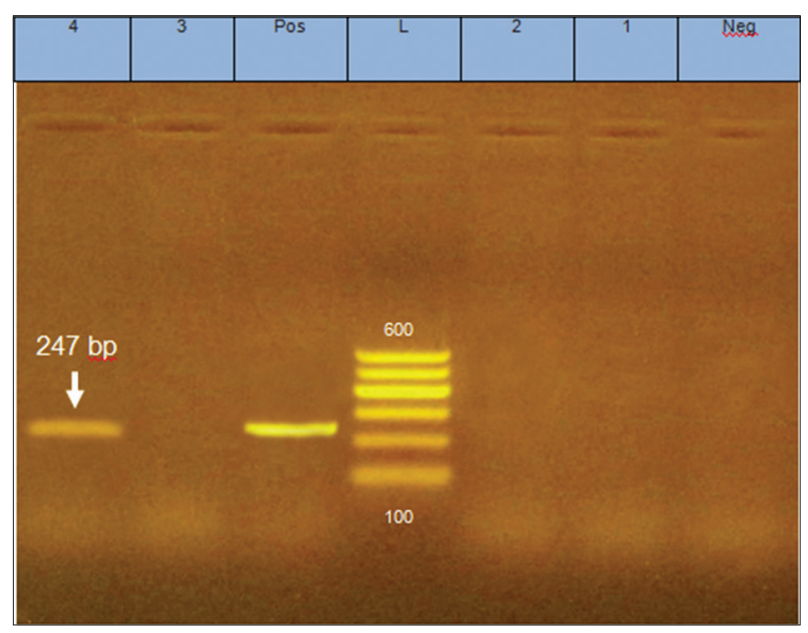

Figure-6: Polymerase chain reaction for the spleen of experimentally infected birds by Marek's disease virus. L - Ladder. Lanes 1-3 - negative amplification of samples (A, C, and E). Lane 4 - positive amplification of sample (K). Lane Pos - positive control.

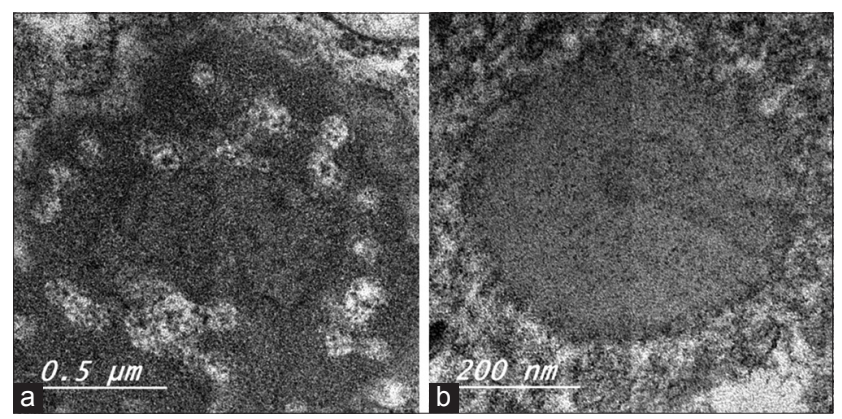

Figure-7: (a-b) Transmission electron microscopy of susceptible breed spleen.

Dandarawi, High Line, and NM205182-G. gallus-B6.1 (Bu-1a) and identity between Sinai, Fayoumi, and Golden Montazah while there is identity between Gimmizah and X92865-G. gallus-B6.3 (Bu-1) and identity between AJ720033-G. gallus-clone 918 and X92867-G. gallus-B6.2 (Bu-1b).

The amino acid sequence showed identity range from $94 \%$ to $100 \%$ to the $C h B 6$ gene in 10 different positive breeds. The hypervariable region $(150 \mathrm{nt})$ contains the most informative genetic data regarding the $C h B 6$ gene, it was chosen for sequence analysis to characterize the sequence of $C h B 6$ in 10 different positive chicken groups (Gimmizah, Sinai, Dandarawi, Fayoumi, Golden Montazah, Matrouh, Beheri, Dokki SPF Lohmann, and High Line) and the relation between them comparing with similar sequences from GenBank. In this study, a comparative alignment and phylogenetic analysis of $150 \mathrm{nt}$ fragments of the amplified $C h B 6$ gene revealed greatest identity. Characterization of the challenge virus isolated from field samples was confirmed by PCR [14,28]. We used $10^{4} \mathrm{PFU}$ of the isolated virus for challenge as reported by Thornton [15].

Trial for the isolation and identification of MDV from spleen collected from challenged birds at 25, 30, 
35 , and 40 weeks' post-infection by PCR assay showed negative results in the breeds containing ChB6 gene while another breed (Bovans) which revealed negative for having $C h B 6$ gene shows positive.

Isolation from spleen as previously reported is the organ of choicer for reisolation [18]. TEM indicated the presence of MDV viral particles in the spleen of Bovans breed to confirm the PCR results. Characteristic MDV viral particles were observed like previously reported [19].

\section{Conclusion}

The study confirms the relationship between the presence of ChB6 gene in our native breed and the absence of tumors. This will need further investigations to enhance the breeding program of such breed in Egypt.

\section{Authors' Contributions}

HAH, MME, and MAS designed and carried out the main research work. The research was carried by HAS, MME, and HAH. The manuscript was written by HAS and HAH. All authors read and approved the final manuscript.

\section{Acknowledgments}

Researchers would like to thank the CLEVB team that has facilitated research facilities.

\section{Competing Interests}

The authors declare that they have no competing interests.

\section{References}

1. OIE Terrestrial Manual. (2017) Marek's Disease. Ch. 2.3.13. World Assembly of Delegates of the OIE, Paris, France.

2. Denesvre, C. (2013) Marek's disease virus morphogenesis. Avian Dis., 57(2): 340-350.

3. McPherson, M.C. and Delany, M.E. (2016) Virus and host genomic, molecular, and cellular interactions during Marek's disease pathogenesis and oncogenesis. Poult. Sci., 95(2): 412-429.

4. Witter, R.L. (1997) Increased virulence of Marek's disease virus field isolates. Avian Dis., 41(1):149-163.

5. Gilmour, D.G., Brand, A., Donnelly, N. and Stone, H.A. (1976) Bu-1 and Thy-1. Two loci determining surface antigens of B or T lymphocytes in the chicken. Immunogenetics, 3(1): 549-563.

6. Tregaskes, C.A., Bumstead, N., Davison, T.F. and Young, J.R. (1996) Chicken B-cell marker ChB6 (Bu-1) is a highly glycosylated protein of unique structure. Immunogenetics, 44(3): 212-217.

7. Bumstead, N. (1998) Genetic resistance to avian viruses. Rev. Sci. Tech. Off. Int. Epiz., 17(1): 249-255.

8. Minias, P., Bateson, W.Z., Whittingham, A.L., Johnson, A.J., McCance, S.O. and Dunn, O.P. (2018) Extensive shared polymorphism at non-MHC immune genes in recently diverged North American prairie grouse. Immunogenetics, 70(3): 195-204.

9. Zhou, H. and Lamont, S.J. (2003) Associations of six candidate genes with antibody response kinetics in hens. Poult. Sci., 82(7): 1118-1126.

10. Reen, J.K., Sankhyan, V., Katoch, S. and Thakur, Y.P. (2013)
Candidate gene polymorphism for IL-R $\gamma$ and ChB6 genes in the indigenous chicken of North Western Himalayan state of Himachal Pradesh, India. Poult. Sci. J., 1(2): 87-92.

11. National Center for Biotechnology Information. Available from: http://www.NCBI.GenBank.Last accessed on 25-10-2017.

12. Bioedit Software(Graphical and biological sequence editor) V 7.2.5 copyright (C) 1997-2013 Tom Hall.

13. MEGA 7 Align Software. V 7.0.21 copyright (C) 1993-2018 Koichiro Tamura, Glen Stecher and Sudhir Kumar.

14. Handberg, K.J., Nielsen, O.L. and Jørgensen, P.H. (2001) The use of serotype 1-and serotype 3-specific polymerase chain reaction for the detection of Marek's disease virus in chickens. Avian Pathol., 30(3): 243-249.

15. Thornton, D.H. (1985) Quality control and standardization of vaccines. In: Payne, L.N., editor. Marek's Disease, Scientific Basis and Methods of Control. Martinus Nijhoff, Boston, MA. p267-291.

16. Gimeno, M.I. and Wakenell, S.P. (2016) Marek's Disease: A Laboratory Manual for the Isolation, Identification, and Characterization of Avian Pathogens. American Association of Avian Pathologists, Athens, Ga. p249-257.

17. Tischer, B.K., Schumacher, D., Beer, M., Beyer, J., Teifke, J.P., Osterrieder, K., Wink, K., Zelnik, V., Fehler, F. and Osterrieder, N. (2002) A DNA vaccine containing an infectious Marek's disease virus genome can confer protection against tumorigenic Marek's disease in chickens. J. Gen. Virol., 83(10): 2367-2376.

18. Schat, A.K. and Nair, V. (2013) Neoplastic disease (Marek's Disease). In: Disease of Poultry. $13^{\text {th }}$ ed. Wiley-Blackwell, Danvers, MA. USA, p513-673.

19. Denesvre, C., Re'my, S., Trapp-Fragnet, L., Smith, L., Georgeault, P.S., Vautherot, J.F. and Nair, V. (2016) Marek's disease virus undergoes complete morphogenesis after reactivation in a T-lymphoblastoid cell line transformed by recombinant fluorescent marker virus. J. Gen. Virol., 97(2): 480-486.

20. Soller, M. and Andersson, L. (1998) Genomic approaches to the improvement of disease resistance in farm animals. Rev. Sci. Technol., 17(1): 329-345.

21. Lamont, S.J. (1998) Impact of genetics on disease resistance. Poult. Sci., 77(8): 1111-1118.

22. Houssaint, E., Diez, E. and Pink, J.R. (1987) Ontogeny and tissue distribution of the chicken $\mathrm{Bu}-1 \mathrm{a}$ antigen. Immunology, 62(3): 463-470.

23. Houssaint, E., Mansikka, A. and Vainio, O. (1991) Early separation of $\mathrm{B}$ and $\mathrm{T}$ lymphocyte precursors in chick embryo. J. Exp. Med., 174(2): 397-406.

24. Gilmour, D.G., Collins, W.M., Fredericksen, T.L., Urban, W.E., Ward, P.F. and DiFronzo, N.L. (1986) Genetic interaction between non-MHC T-and B-cell alloantigens in response to Rous sarcomas in chickens. Immunogenetics, 23(1): 1-6.

25. Taylor, R.L., Medarova, Z. and Briles, W.E. (2016) Immune effects of chicken non-MHC alloantigens. Poult. Sci., 95(2): 447-457.

26. Groenen, M.A., Cheng, H.H., Bumstead, N., Benkel, B.F., Briles, W.E., Burke, T., Burt, D.W., Crittenden, L.B., Dodgson, J., Hillel, J., Lamont, S., de Leon, A.P., Soller, M., Takahashi, H. and Vignal, A. (2000) A consensus linkage map of the chicken genome. Genome Res., 10(1): 137-147.

27. O'Laughlin, J.P. (2010) Genetic Diversity of the ChB6 Alloantigen, College of Liberal Arts and Social Sciences Theses and Dissertations. Paper 18. Available from: http:// www.via.library.depaul.edu/etd/18. Last accessed on 18-02-2018.

28. Bumstead, N., Sillibourne, J., Rennie, M., Ross, N. and Davison, F. (1997) Quantification of Marek's disease virus in chicken lymphocytes using the polymerase chain reaction with fluorescence detection. J. Virol. Methods, 65(1): 75-81. 